\title{
BOR DERGISI

A Comparative study on the effect of acute toxicity of nano and micro boron particles in Lemna minor (Linneaus 1753)

\author{
Yeşim Dağlıoğlu' ${ }^{1 *}$, Sevda Türkiş ${ }^{2}$ \\ ${ }^{1}$ Ordu University, Department of Molecular Biology and Genetics, Ordu, 52200, Turkey \\ ORCID orcid.org/0000-0001-8740-1162 \\ ${ }^{2}$ Ordu University, Faculty of Education, Department of Primary Education, Ordu, 52200, Turkey \\ ORCID orcid.org/0000-0002-1853-8437
}

\section{ARTICLE INFO}

Article History:

Received April 26, 2020

Accepted April 4, 2021

Available online June 30, 2021

Research Article

DOI: $10.30728 /$ boron.727172

\section{Keywords:}

Antioxidant activity

Boron

Lipid peroxidation

Nanoparticles

Oxidative stress

\begin{abstract}
In recent years, research on the fate of engineering nanoparticles on plants and their toxicity mechanisms have indicated that there are knowledge gaps and significant uncertainties. In this study, the toxicity, physiological effects, and basic factors of nano and micro boron particles treated to duckweed (Lemna minor) under experimental conditions were investigated. This study reports that the chlorophyll concentration of treated nano boron is higher than the control group and the treated micro boron. Malondialdehyde and superoxide dismutase levels were recorded higher in micro boron. Catalase and hydrogen peroxide level was recorded higher in nano boron. Pearson's correlation analysis indicated negative correlations between hydrogen peroxide and malondialdehyde levels in all doses of nano boron; Positive correlations were found between malondialdehyde and catalase levels at $100 \mathrm{mgL}^{-1}$ of micro boron. As the concentration of the treated nano boron increased, the rate of accumulation in the leaf tissues of duckweed decreased. On the contrary, micro boron was observed to be the opposite. When all these data are evaluated, it is understood that micro boron is more toxic than nano boron.
\end{abstract}

\section{Introduction}

The behaviors of nanoparticles (NPs) in different environmental risks, such as natural waters, sediment, and soils are complex. Once in the environment, NPs suffer transformations such as aggregation that can affect ecotoxicity [1-4]. Today, there are many types of NPs and their industrial uses have increased rapidly. Consequently, the potential biological effect and environmental end of NPs raise concerns. In the last decades, scientists have investigated nanoparticle ecotoxicity to learn more about the risks and benefits of NPs [4].The likelihood of exposure of plants to NPs has increased with the use of NPs in a production of various tools and goods [5-6]. The access of the NPs to the plants is through direct application, accidental release, contaminated soil/sedimentation, or atmospheric precipitation. As plants interact strongly with atmospheric, terrestrial and aquatic environments, they are exposed to NPs [7]. Based on the literature, it has been stated that properties such as the uptake, displacement, and accumulation of NPs in plants depend on the size, type, chemical compound, functionality, and determination of the NPs $[6,8,9]$. In addition, the plant cell wall serves as a barrier for any foreign substance, including NPs can not easily enter the plant cells since the pore di- ameter is between 5-20 nm [10]. However, by affecting cell walls, NPs can cause the formation of large and new pores that allow large NPs to pass through the cell wall $[11,12]$. Thus, NPs or NP aggregates can easily pass through the cell walls and reach plasma membranes as they have a smaller diameter than the pore diameter of the cell walls $[13,14]$.

The world's boron (B) minerals' (about 230 kinds of) approximately $62 \%$ of reserves are in Turkey. B compounds having a very wide and widespread use area are increasingly used. It is used in a wide variety of areas, from fertilizer to the pharmaceutical industry, from cleaning material to the nuclear industry [15]. In recent years, boron has become a more popular field of use and has a a broad range of practices in protective coatings, high-density fuels, cancer treatments, and semiconductor fields $[16,17]$. So, plants are exposed to $B$ at a higher rate. The beneficial role of Micro $B$ against plant growth was recorded in earlier studies. The most important role that bor plays in plant metabolism is the protection of hormone levels [18]. Although, the effect of nano $B$ on plant development is not well known yet. Therefore, in this study, photosynthesis (chlorophyll fluorescence), oxidative stress, antioxidant defense system, and accumulation of nano and 
micro B particles in Lemna minor were compared in the same conditions. As a result, the ecotoxicity of the micro and the nanoparticles therefrom was evaluated as comparative. Nowadays, we think that our study will contribute to the literature and present a different point of view to the ecotoxicity experiments, as there are very few studies comparing the toxicity of materials at nano and micro sizes.

Chloroplasts are the main source of reactive oxygen species (ROS) in plants. The main types of ROS are superoxide $\left(\mathrm{O}_{2} \cdot{ }^{-}\right)$, hydrogen peroxide $\left(\mathrm{H}_{2} \mathrm{O}_{2}\right)$, and hydroxyl radicals $\left(\mathrm{OH}^{\circ}\right)$ [19]. The transformation of superoxide into hydrogen peroxide can cause problems for plants because it causes the Calvin cycle to be blocked [20]. This prevents the formation of carbohydrates. The most significant photosynthetic pigments in plants are Chlorophyll a and b. Light energy is stored as chemical energy for the production of oxygen [21]. The quantity of sunlight absorbed by a plant is largely a function of the concentrations of chlorophyll pigment. For this reason, poor concentrations of photosynthetic pigment can limit direct photosynthesis potential and therefore main production [22]. Under environmental stress of plants, chlorophyll content and photosynthetic structure behavior may change and thus affect whole plant metabolism [23]. The most widespread indicator of oxidative stress occurring in plants is lipid peroxidation causing disruption in membrane integrity [24]. In addition, cell membrane permeability and the activities of antioxidant enzymes (SOD and CAT) indicate the tolerance of plants to stress. Previous studies have documented that metal and metal oxide NPs reason oxidative stress $[25,26]$. For example, a significant reduction in frond numbers and a decrease in plant cellular viability of Lemna gibba applied to AgNP concentration of $0.1-10 \mathrm{mgL}^{-1}$ have been detected. This effect is highly correlated with intracellular reagent production [27]. Abiotic stress conditions cause the formation of highly toxic and reactive molecules called ROS in plants. Thus, ROS causes oxidative stress by disrupting the protein, lipid, carbohydrate and DNA structure of cells. Oxidative stress caused by ROS production is deteriorated in the cell membrane due to lipid peroxidation, which is evaluated by measurement of malondialdehyde (MDA) [28]. When ROS increases, chain reactions begin, that is, catalyze the conversion of superoxide dismutase (SOD) superoxide radicals to molecular oxygen and $\mathrm{H}_{2} \mathrm{O}_{2}$. The plants have antioxidant defense systems to prevent these damages. These antioxidant systems are divided into enzymatic and non-enzymatic [29]. Factors that play a key role in the formation of NP-derived ROS are active redox cycling and particle cell interactions on nanoparticle surfaces due to the passage of pro-oxidant functional groups and metal-based NPs on the reactive surface of NPs [30,31]. Various NPs have been indicated to form ROS both in vitro and in vivo. For example, in one study, cellular ROS production was observed to be caused by various NPs such as $C_{60}$, single-walled carbon nanotube (SWCNT), quantum dots, and ultrafine particles [32].

In this study, Lemna minor, an aquatic plant, has used to assess the potential risk of nano and micro B particle suspension. L. minor is a suitable indicator water organism for toxicological investigations. It is proven that the water plant is highly sensitive to the toxic effects of pollutants and prevents photosynthesis and plant growth by pollutants [27,33-36]. The comparative toxic effect of nano and micro B particle suspension has been investigated in relation to the modify in the physiological state of $L$. minor and the bioaccumulation in intracellular B particles. The physiological case of $L$. minor which was exposed to nano and micro $B$ particle under stress conditions was determined by the concentration of chlorophyll a (chl-a), chlorophyll $\mathrm{b}$ (chl-b) and $\mathrm{a}+\mathrm{b}$ (photosynthetic pigments), hydrogen peroxide $\left(\mathrm{H}_{2} \mathrm{O}_{2}\right)$, and malondialdehyde (MDA) with antioxidant enzyme activity such as superoxide dismutase and catalase. The effects of bulk material (micro boron) and nano boron materials on the plant have been investigated. The data obtained were evaluated by comparing these two forms (nano and micro). In this respect, it contains differences from many studies that are currently available in the literature. In addition, it is different from the studies in the literature as the studies conducted are evaluated not from a single aspect but from several different aspects. These different aspects are accumulation, cell damage, and chlorophyll concentration, and antioxidant enzyme activities. All these analyzes have been evaluated and interpreted together.

\section{Materials and Methods}

\subsection{Materials}

\subsubsection{Plant materials}

Lemna minor used in the bioassay experiment was gathered in Muğla from Turkey. The L. minor was kept at $23^{\circ} \mathrm{C}$ and $14 / 10$ (light/dark) photoperiod for experimental studies.

\subsubsection{Boron materials}

Commercially available micro boron was provided as a powder of $95 \%$ purity, average size $>100 \mathrm{~nm}$, and nano boron $95 \%$ purity average size $<90 \mathrm{~nm}$. Boron particles, boron particles were obtained from Pavezyum Chemicals, Turkey.

\subsection{The Preparation of the Test Solution}

An aqueous suspension of nano and micro B particles at concentrations of $0,50,100$, and $200 \mathrm{mgL}^{-1}$ was prepared with deionized water in the dispersion medium. Afterwards, this solution was vortexed for 20 seconds. While preparing aqueous suspension of the 
NPs, ultrasonic water bath (Bandelin, sonorex, Berlin, Germany) was used for 30 minutes in order to boost the dispersion in water.

\subsection{Treatment Procedures of Boron Particles into the Duckweed}

Lemna minor grown in laboratory conditions were exposed to $\mathrm{B}$ particles at $23^{\circ} \mathrm{C}$ and $14 / 10$ (light/dark) photoperiod in $500 \mathrm{ml}$ polyethylene bottles. Since most NPs tend to aggregate in an inert media, experiments must be carried out in the mobile system to ensure the natural conditions of the plants. For these reasons, it is necessary to provide a continuous moving environment during the experiment. In this study, an aquarium air motor was used to provide the mixture in the exposure test. Plant samples were exposed to B particles for 96 hours in the modified Hoagland nutrient solution, a mineral nutrient medium [27].

\subsection{Measurement of Antioxidant Activity in the Duckweed Treated with Boron Particles}

Superoxide dismutase (SOD) activity was measured as defined by Beauchamp and Fridovich [37]. Briefly, one unit is described as the quantity of enzyme that causes a $50 \%$ reduction by nitro blue tetrazolium (NBT). SOD was determined by inhibition of NBT at $560 \mathrm{~nm}$. Catalase (CAT) activity was defined using the method of Jebara by monitoring the early rate of the decrease in absorbance at $240 \mathrm{~nm}$ by the of $\mathrm{H}_{2} \mathrm{O}_{2}$ reduction over one minute [38].

\subsection{Assessment of Lipid Peroxidation in the Duck- weed Treated with Boron Particles}

Thiobarbituric acid (TBA) was used to determine malondialdehyde (MDA), the final product of lipid peroxidation. $200 \mathrm{mg}$ of the plant was homogenized in $10 \mathrm{ml}$ of $0.1 \%$ trichloroacetic acid (TCA) solution. The homogenate obtained was centrifuged at $15000 \mathrm{~g}$ for $15 \mathrm{~min}$. The reaction mixture containing $1 \mathrm{ml}$ of supernatant and $4 \mathrm{ml}$ of TBA was heated in a hot water bath at $90^{\circ} \mathrm{C}$ for 20 minutes and right off cooled in ice bath. The absorbance of the MDA-TBA mixture centrifuged at $15000 \mathrm{~g}$ for 15 minutes was then determined at a wavelength of $532 \mathrm{~nm}$. This amount of the MDA-TBA mixture was calculated from the absorbance coefficient $[37,39,40]$.

$M D A(n m o l / m l)=\left[\left(A_{532}-A_{600}\right) / 155000\right] \times 10^{6}$

\subsection{Determination of $\mathrm{H}_{2} \mathrm{O}_{2}$ in the Duckweed Treat- ed with Boron Particles}

The level of $\mathrm{H}_{2} \mathrm{O}_{2}$ was identified according to the process expressed by Mukherjee and Choudhuri with minor changes [39]. Firstly, the titanium solution was prepared. For this, $1 \mathrm{gram}$ of $\mathrm{TiO}_{2}$ and $10 \mathrm{~g}$ of $\mathrm{K}_{2} \mathrm{SO}_{4}$ were boiled in $150 \mathrm{ml}$ of concentrated $\mathrm{H}_{2} \mathrm{SO}_{4}$ on the hot plate for 2 hours and cooled. Then 1.5 liters completed. 0.5 gram of the plant was mix well with $10 \mathrm{ml}$ of cold acetone and the mix filtered through glass fiber filters (Whatman GF/F, $47 \mathrm{~mm}$ ). $4 \mathrm{ml}$ of $\mathrm{TiO}_{2}$ solution and $5 \mathrm{ml}$ of concentrated $\mathrm{NH}_{3}$ solution were joined to the extract. Then this solution centrifuged at 10000 $\mathrm{g}$ for $10 \mathrm{~min}$. and the supernatant poured out and the precipitate dissolved with $10 \mathrm{~mL}$ of $1 \mathrm{M} \mathrm{H}_{2} \mathrm{SO}_{4}$. Again, this process was repeated at $10000 \mathrm{~g}$ for 5 minutes, the insoluble fraction was discarded and $\mathrm{H}_{2} \mathrm{O}_{2}$ at 415 $\mathrm{nm}$ was detected $[39,40]$.

\subsection{Chlorophyll Analysis in the Duckweed Treated with Boron Particles}

$10 \mathrm{ml} 80 \%(\mathrm{v} / \mathrm{v})$ acetone solution and $300 \mathrm{~g}$ quartz sand were added to the plant and crushed. The extract obtained was taken into a centrifuge tube and $4 \mathrm{ml}$ of $80 \%$ acetone was added. After centrifugation, the extract was filtered owing to Whatman black-band filter paper and the final volume was brought to $10 \mathrm{ml}$. The Liquid was read in the spectrophotometer at 663 to $645 \mathrm{~nm}$. The amount of chlorophyll pigment was calculated using Equations 2 and 3 where $D$ is wavelength, $V$ is $100 \%$ end volume of acetone and $A$ is weight of leaf tissue in grams [41].

$\mathrm{Chl}-\mathrm{a}(\mathrm{mg}) /$ Tissue $(g)=\left[12.7\left(D_{663}\right)-2.69\left(D_{645}\right)\right] \times(V / 100 \times A)$

$\mathrm{Chl}-\mathrm{a}(m g) /$ Tissue $(g)=\left[22.9\left(D_{645}\right)-4.68\left(D_{663}\right)\right] \times(V / 100 \times A)$

\subsection{Determination and Digestion of Boron Parti- cles}

The plant samples were placed on drying papers and dried for 24 hours at $80^{\circ} \mathrm{C}$ in a drying oven. Dried samples were first filtered by burning in a mixture of concentrated $10 \mathrm{ml} \mathrm{HNO}_{3}$ (nitric acid). All examples were examined using Perkin Elmer Elan DRC-e inductively coupled plasma-mass spectrometry (ICP-MS, Shelton, USA) for boron analysis.

\subsection{Statical Analysis}

SPSS 22.0 program was used to determine significant differences. Multifactor analysis of variance (ANOVA) was used to define statistical differences in the various criteria between obtained plant data. Tukey's mean separation tests were applied if $F$-values from the ANOVA were significant at the $P<0.05, P<0.01$, and $P<0.001$ levels.

\section{Results and Discussion}

\subsection{Results}

\subsubsection{Chlorophyll concentration in L. minor}

In Figure 1, it is observed that, when the concentration of nano $\mathrm{B}$ increased, the $\mathrm{Chl}-\mathrm{a}$ and $\mathrm{Chl}-\mathrm{b}$ decreased, whereas, in the micro $B$ treatment, opposite findings were registered. Compared with the control group, the 
Chl a

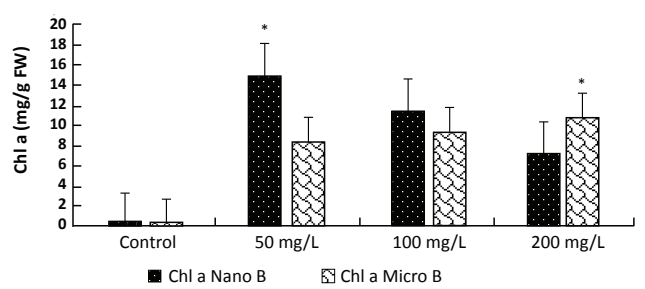

$\mathrm{Chl} \mathrm{a/b}$

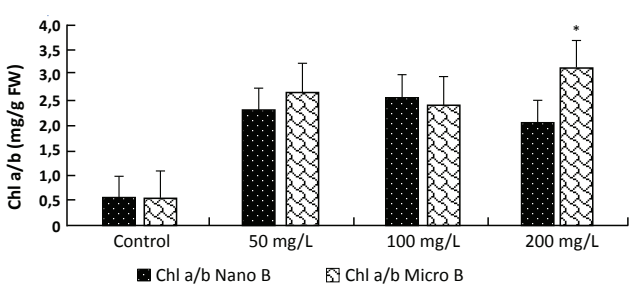

Chl b

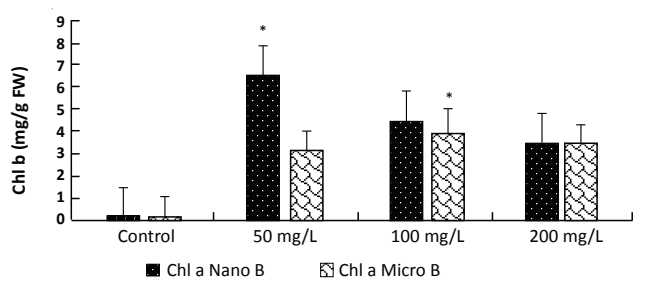

Chl a+b

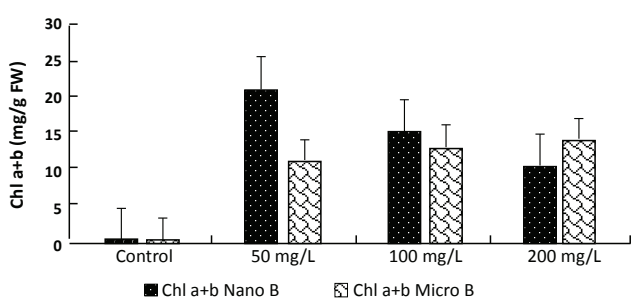

Figure 1. The assessment of pigment contents versus time in $L$. minor exposed to nano and micro B particles. Values indicate mean \pm standard deviation. Those with different stars on error bar are significantly different $(P<0.001$, Tukey multiple comparison).

concentration of both Chl-a and Chl-b are higher in the groups exposed to $B$ particles. The maximum concentration of $\mathrm{Chl}-\mathrm{a} / \mathrm{b}$ was calculated at $100 \mathrm{mgL}^{-1}$ in nano $\mathrm{B}$ and $200 \mathrm{mgL}^{-1}$ in micro B. The values Chl-a+b of treatment groups were calculated to be higher than that of the control group, and it was calculated the highest as $50 \mathrm{mgL}^{-1}$ for nano $\mathrm{B}$ and $200 \mathrm{mgL}^{-1}$ for micro $\mathrm{B}$.

\subsubsection{Oxidative stress and tissue damage caused by boron particles}

The exposure of duckweed to 50, 100, and $200 \mathrm{mgL}^{-1}$ nano and micro $B$ particles under $23^{\circ} \mathrm{C}$ and $14 / 10$ (light/ dark) photoperiod conditions resulted in significant differences in SOD and CAT activities, MDA and $\mathrm{H}_{2} \mathrm{O}_{2}$ levels, and both groups (nano and micro $B$ treatment group) indicated significant differences in B particle concentrations. The maximum SOD activity in the nano $B$ particle was recorded at $100 \mathrm{mgL}^{-1}$. At 50 and 200 $\mathrm{mgL}^{-1}$, SOD activity was lower than the control group, especially at $50 \mathrm{mgL}^{-1}$, and it was measured almost half of the control group. SOD activity for nano B was low in all treatment groups compared to the control and exposed groups of micro B particles. The least SOD activity was measured in the lowest concentration group, $50 \mathrm{mgL}^{-1}(P<0.001)$. CAT activity in nano $\mathrm{B}$ is much higher in treatment groups of micro $B$ and than the control group. The highest CAT activity in exposed groups was reported $200 \mathrm{mgL}^{-1}$ and the lowest CAT activity at $100 \mathrm{mgL}^{-1}$. The CAT activity of micro $B$ was higher in all treatment groups except the $200 \mathrm{mgL}^{-1}$ concentration compared to the control group.

Identification of the amount of MDA, a product that results from the oxidation of lipids as a result of destruction in cell membranes, can give information about the reaction of $L$. minor to nano and micro $B$ particles. According to this, MDA values reached its highest value at $100 \mathrm{mgL}^{-1}$ concentration in both $B$ particles. The MDA level of micro $B$ is higher than nano $B$. Whereas, 200 $\mathrm{mgL}^{-1}$ of micro $B$ with $50 \mathrm{mgL}^{-1}$ nano $B$ were found to have a lower MDA value than the control group. The $\mathrm{H}_{2} \mathrm{O}_{2}$ level of the nano B was significantly lower $50 \mathrm{mgL}$ ${ }^{1}$ compared to the control group. The highest production was $100 \mathrm{mgL}^{-1}$ and $200 \mathrm{mgL}^{-1}$ was slightly higher in the control group. At all concentrations in micro $\mathrm{B}$, the $\mathrm{H}_{2} \mathrm{O}_{2}$ level was higher than the control group and values were close to each other (Figure 2).

\subsubsection{Correlation between test results}

Correlations were executed among the MDA, SOD, $\mathrm{H}_{2} \mathrm{O}_{2}$, and CAT results of the $L$. minor leaf concentration of nano and micro $B$ applied at different concentrations. According to the Pearson correlation results, the correlation between only the nano $B$ concentration of different doses of nano and micro $B$ particles in leaf tissue of the L. minor was determined. Accordingly, MDA indicated a positive correlation with both SOD and $\mathrm{H}_{2} \mathrm{O}_{2}$. However, a positive correlation was also found between SOD and $\mathrm{H}_{2} \mathrm{O}_{2}$ (Table 1).

\subsubsection{Accumulation of B particles in L. minor}

In Figure 1, as a effect of exposure to B nano and micro particles for $96 \mathrm{~h}$, the accumulation in leaf tissues of the $L$. minor reduced by the increase in the concentration of nano $B$. On the contrary, micro $B$, as the concentration of micro $B$ increases the accumulation of plant tissue. Significant differences were found at the levels of $P<0.001$ in terms of accumulation between different concentrations of the nano and micro $B$ particles in L. minor. According to Tukey's test results, these differences are due to the maximum accumulation in plant tissue at $50 \mathrm{mgL}^{-1}$ for nano $\mathrm{B}$ and 200 $\mathrm{mgL}^{-1}$ for micro B (Figure3).

\subsection{Discussion}


SOD

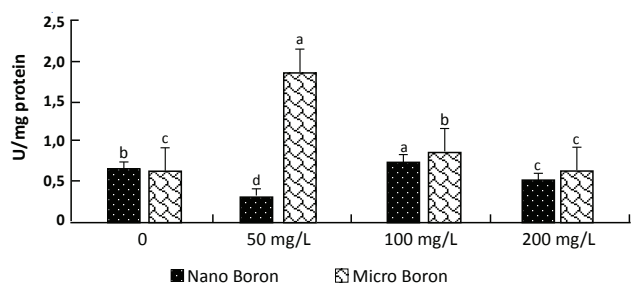

$\mathrm{H} 2 \mathrm{O2}$

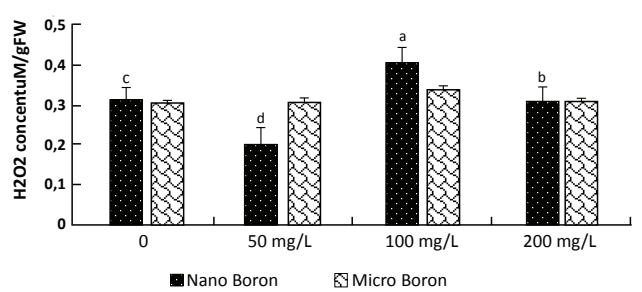

CAT

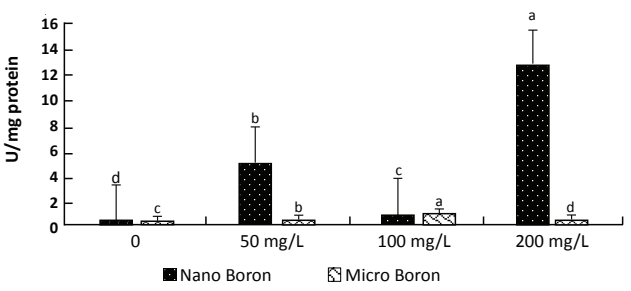

MDA

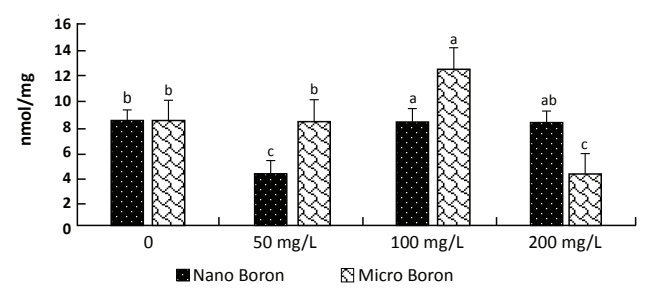

Figure 2. Activitiy of (a) SOD and (b) CAT, and levels of (c) $\mathrm{H}_{2} \mathrm{O}_{2}$, and (d) MDA in L. minor leaf tissue following its exposure to nano and micro $\mathrm{B}$ particles for $96 \mathrm{~h}$. They were exposed under control group and B particle conditions; values indicate the mean and the error bars indicate standard deviation.

Macrophytes are used in laboratory tests to determine the toxicity of potential contaminants. Macrophytes such as $L$. minor are preferred species in toxicity tests. Because they are often used as a representative species for all other vascular plants [42]. Rapid and pre- cise techniques are needed to assess the effects of NPs on L. minor. One of these techniques is Chl-a, which is a fast technique for measuring the photosynthetic electron transport in these plants. Due to its role in the Chl-a light collection complex and its presence

Table 1. Pearson correlation results of different doses of nano and micro B particles.

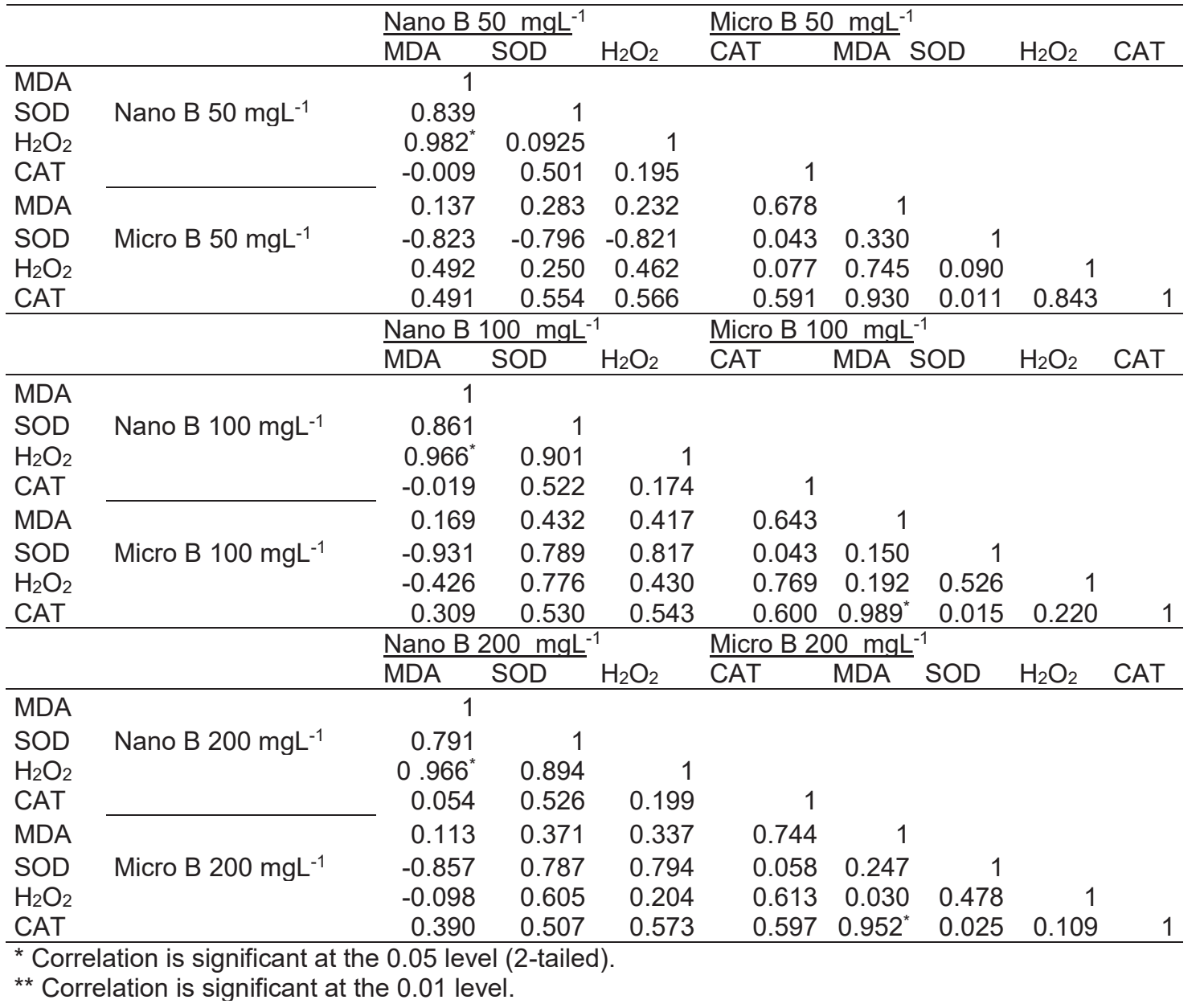




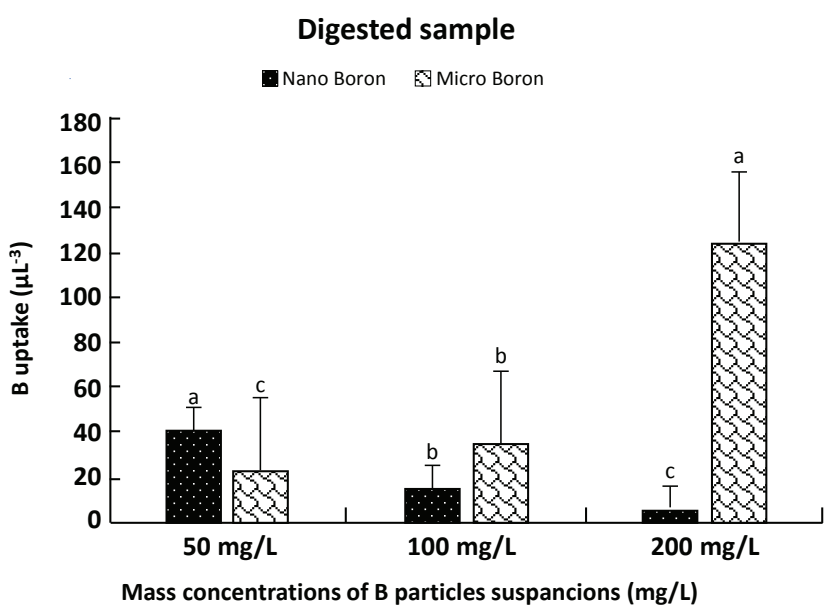

Figure 3. Comparison of ICP-MS analysis of internalized nano and micro boron particles in Lemna minor after exposure to $50-200 \mathrm{mgL}$ ${ }^{1}$ boron particles during 96 hours.

in the PSII reaction center as the electron supplier of the photovoltaic electron transport chain, it causes more photodegradation than other photosynthetic pigments [43]. In our study, Chl-a concentration was much higher in nano and micro boron treated groups compared to the control group. When nano and micro $B$ are compared with each other, in nano $B$, Chl-a decreased as the concentration increases and in micro $B$ also occurred in the opposite, and at higher concentrations Chl-a is increased. This situation has been proven in many studies by enhancing the electron transfer efficiency of the photosynthetic reaction centers of NPs [44,45]. As an example of this, Juhel et al. [46] noted that aluminum oxide $\left(\mathrm{Al}_{2} \mathrm{O}_{3}\right) \mathrm{NPs}$ enhance $L$. minor growth. However, the possible cause of the decline of the Chl-a with increasing nano $\mathrm{B}$ particle concentration is the surface area of the nanoparticle dose is likely to correlate well with the toxicity of the nanoparticle dose, and this is an alternative to the classical mass dose [47-49]. In addition, although the nanotoxicity mechanism is not fully known, it has been noted that the chemical composition and structure of the nanoparticles, particle size and surface area volume ratio are closely related to the toxicity. Toxicity of nanoparticles may occur as a result of chemical toxicity based on the chemical composition, such as the release of (toxic) ions, or as stresses or stimuli that are generated by factors such as the surface, size, shape of the particles. In addition, the nanoparticle surface area is an important factor that directs particle reactivity and the formation of oxidants and free radical activity [50]. In this study, the likely cause of the change in Chl-a concentration in nano B treated groups is the toxicity associated with the increasing surface area of the nano $\mathrm{B}$, depending on the concentration. Because, as the nano $\mathrm{B}$ concentration increases, the $\mathrm{Chl}-\mathrm{a}$ decreased (In groups treated with $200 \mathrm{mgL}^{-1}$ nano B according to $50 \mathrm{mgL}^{-1}$, Chl-a concentration decreased by $50 \%$ ). Thus, the Chl-a measurement can function as a delicate parameter in assessing growth inhibition and can be used as a stimulus to nanoparticle exposure. However, when evaluated generally, the Chl-a concentration is higher in the $B$ treated groups than in the control group. Probably the reason for this is that boron is an indispensable nutrient for plants. Furthermore, there is a very delicate balance between boron deficiency and toxicity in plants. Plants need an very small amount of boron, which is involved in protein synthesis. The excess of $B$ has a negative effect on the growth as in B deficiency. The excess of B (even if very little) has a negative effect on the development as in boron deficiency [51]. In our study, toxicity was not observed in the conventional B (micro B) concentrations and the high $\mathrm{B}$ concentration increased the Chl-a concentration (for example, micro B increased $29 \%$ at $200 \mathrm{mgL}^{-1}$ compared to $50 \mathrm{mgL}^{-1}$ in the treated groups. Dawis et al.) reported that leaf production in duckweed (Spirodella polyrrhiza) exposed to B decreased considerably in $3.55 \mathrm{mg} \mathrm{B/l}$ of $B$ [52]. However, reductions in growth rate and percentages of abnormal leaves (chlorosis, necrosis and death percentages) were not apparent up to 18.9 and $22.4 \mathrm{mg} \mathrm{B/l}$. The Chl-b concentration of nano $B$ treated groups decreased at high concentration as in Chl-a. Chl b, the decrease was $16 \%$ and $49 \%$ in response to the 100 and $200 \mathrm{mgL}^{-1}$ nano $B$ treatment, respectively, compared to $50 \mathrm{~g} / \mathrm{L}$ nano $B$. However in micro B treated groups, the Chl-b concentration remained almost the same. In the case general state of chlorophyll, the increase was much higher in response to the nano and micro $B$ treatment, respectively, compared to the control. $7 y$ is not $y$ in chla reaction centers, only in reaction centers of photosystems. However, Chl-b is found in both. The chl-a/b ratio is an indicator of the amount of light captured by the leaf (Figure 1) [21]. In some studies it has been determined hat the chlorophyll a ratio of $\mathrm{Chl}-\mathrm{a}$ increases $[53,54]$. It is stated that Chl-b decays before Chl-a or Chl-b turns into Chl-a [53]. There are differences in enzymatic activities in plant tissues under different stress conditions. Adaptation of the plant to these conditions depends on qualitative and quantitative metabolic changes [55]. The existence of free radicals in living things was discovered almost 50 years ago [56]. Following this discovery, in 1956 Denham Herman hypothesized that oxygen radicals could come into being as products of in vivo enzymatic reactions [57]. The preservation of the structural unity of and tissues cells and the preserve of the current balance among the antioxidant system and oxidant the in fulfilling their normal function is of great importance. The degradation of this balance causes the oxidative stresses in the organism. Free radicals which formed and the reactive oxygen molecules which oxidative damage the fundamental structural molecules of the organisms, proteins, DNA and lipids [58,59]. Plant cells have a protective repair system that minimizes the level of oxidative damage. Antioxidants react with active oxygen derivatives, thus drawing the level of these harmful radicals below the level of damage. These damag- 
es can be analyzed in the cell by the change of certain antioxidant enzymes such as SOD, CAT, POX. SOD which converts superoxide to $\mathrm{H}_{2} \mathrm{O}_{2}$. These are an indispensable component of antioxidant defense system in plants [60]. In this way, the superoxide molecule is reduced to a lower concentration. $\mathrm{H}_{2} \mathrm{O}_{2}$ is not radical because it does not include unmated electrons in its structure, but it can easily diffuse into or through cells passing through biological membranes and become a long-lived oxidant $[61,62]$. In biological systems, the actual production of $\mathrm{H}_{2} \mathrm{O}_{2}$ is transformed to $\mathrm{H}_{2} \mathrm{O}_{2}$ by the reaction of superoxide nonenzymatic or SOD catalysed dismutation. In addition, $\mathrm{H}_{2} \mathrm{O}_{2}$ is produced in vivo as a result of the action of certain oxidase enzymes such as amino acid oxidase, xanthine oxidase [63]. CAT is one of the major enzymes that scavenge reactive oxygen species in plant cells. CAT attend in the basic defense system against the backlog and toxicity of $\mathrm{H}_{2} \mathrm{O}_{2}$ and can function in the control of the amount of $\mathrm{H}_{2} \mathrm{O}_{2}$ in the cells. The CAT is destructive of $\mathrm{H}_{2} \mathrm{O}_{2}$. CAT activity, however, decreases at cold temperatures and stress conditions such as herbicide applications [64]. Peroxidation occurs in membrane lipids when the free radical level passed the antioxidant capacity of the cell [65-69]. Lipid peroxidation is terminated by the conversion of lipid hydroperoxides to aldehydes and other carbonyl compounds. Measuring the amount of malondialdehyde is a frequently used stress indicator for the detection of lipid peroxide levels [70]. Previous studies have shown that heavy metals lead to peroxidation of cell wall lipids by removing hydrogen from unsaturated fatty acids function ROS [71]. The level of MDA, an indicator of lipid peroxidation, is also an indicator of cell damage. [72]. Nanoparticles have been reported to cause oxidative stresses in various studies, such as in heavy metals. For example, $\mathrm{Fe}_{3} \mathrm{O}_{4} \mathrm{NP}$ expose induced antioxidant enzyme and oxidative stress activities in ryegrass and pumpkin plants. Also, in both plants, oxidative stress is quite high on the roots compared to the shoots [73]. Oxidative stress in sand-grown wheat exposed with copper(II) oxide ( $\mathrm{CuO}$ ) and zinc oxide $(\mathrm{ZnO})$ nanoparticles has been demonstrated by rised lipid peroxidation and decreased chlorophyll concentration in shoots [74]. Our study, a important rise in the lipid peroxidation of some treatment groups was observed when the nano and micro B particle applications were compared to the control group. At the SOD and CAT amounts, which were measured as antioxidant status indications, there was a significant increase in treatment groups (100 and $200 \mathrm{mgL}^{-1}$ for nano $B$ and 50 and $100 \mathrm{mgL}^{-1}$ for micro B) when compared to the control group. It is known that ROS can quickly assault lipids and cause irreversible membrane damage. $\mathrm{H}_{2} \mathrm{O}_{2}$ in the cell acts as a signaling molecule and can also cause membrane damage due to its high permeability along the membranes. The fact that $\mathrm{H}_{2} \mathrm{O}_{2}$ is a pointing or harmful molecule depends on the sensitive balance between production and excretion in the cell [75]. In this study,
$\mathrm{H}_{2} \mathrm{O}_{2}$ production increased in all treatment groups of micro $B$ and other treatment groups except the lowest treatment group of nano B And MDA induced. Given both SOD and CAT activity, both antioxidant enzymes have eliminated the $\mathrm{H}_{2} \mathrm{O}_{2}$ surplus by avoiding potential lipid damage at a minimum level is caused by $\mathrm{B}$ particles. For example, the highest $\mathrm{H}_{2} \mathrm{O}_{2}$ produced a treatment group of $100 \mathrm{mgL}^{-1}$ of nano $\mathrm{B}$ (2.7 times greater than the control group) and the activity of SOD and CAT increased in the cell to removed this $\mathrm{H}_{2} \mathrm{O}_{2}$. In particular, although CAT activity increased 3.7-fold over the control group, MDA production can not prevented. The level of $\mathrm{H}_{2} \mathrm{O}_{2}$ is very low in the treatment groups $50 \mathrm{mgL}^{-1}$ for nano $B$ and the $200 \mathrm{mgL}^{-1}$ for micro $B$ and could not initiate lipid peroxidation. In this study, MDA, $\mathrm{H}_{2} \mathrm{O}_{2}$ levels and SOD and CAT activities were evaluated together; In general, micro $B$ is more toxic than nano B. However, the more the B toxicity in the L. minor, the more successfully the antioxidant defense system has been used to avoid these toxic effects. It can also be assumed here that $\mathrm{H}_{2} \mathrm{O}_{2}$ functions as a signaling molecule because there is a balance between cell production and excretion. Briefly, the level of free radicals in $L$. minor exposed to $B$ particles have exceeded the antioxidant capacity of the cell and peroxidation occurred in membrane lipids. When we look at the previous studies on the $L$. minor, it is seen that the results are similar to our results. Some of these studies are; After L. minor treated to CuO NPs and bulk $\mathrm{CuO}\left(10-500 \mathrm{mgL}^{-1}\right)$ the effects on the preventive enzymes (SOD, CAT, and POD) and the MDA level were examined. Accordingly, the SOD activity of the plant increased $\mathrm{CuO} \mathrm{NP}$, bulk $\mathrm{CuO}$, with the increase of $2 \mathrm{x} \mathrm{Cu}^{2+}$ released from $\mathrm{CuO} \mathrm{NP}$ in the culture medium and the bulk $\mathrm{CuO}$ concentration increased remarkably until it reached $100 \mathrm{mgL}^{-1}$. L. minor teated to $\mathrm{CuO}$ NPs has accumulated a superoxide radical at low concentration and the $\mathrm{Cu}^{2+}$ release to the culture medium served as a crucial factor in increasing SOD activity. Again CAT activity and MDA content have increased $\mathrm{CuO} \mathrm{NP}$, bulk $\mathrm{CuO}$ and with the increase in $2 \mathrm{x} \mathrm{Cu}^{2+}$ released from the $\mathrm{CuO}$ NP [76]. In studying the effect of $\mathrm{TiO}_{2} \mathrm{NPs}$ and bulk $\mathrm{TiO}_{2}$ on $L$. minor preventive enzymes; SOD activity was increased by the increase of $\mathrm{TiO}_{2} \mathrm{NP}$ when the concentration of $\mathrm{TiO}_{2} \mathrm{NP}$ was below $100 \mathrm{mgL}^{-1}$ and when the concentration of $\mathrm{TiO}_{2} \mathrm{NP}$ was higher than $100 \mathrm{mgL}^{-1}$, the SOD activity of $L$. minor reduced. It was noted that the SOD activity of $L$. minor in bulk $\mathrm{TiO}_{2}$ environment did not indicate a significant increase compared to the control group until the bulk $\mathrm{TiO}_{2}$ concentration reached $2000 \mathrm{mgL}^{-1}$. The level of MDA increased with the increase of $\mathrm{TiO}_{2} \mathrm{NP}$ in culture medium. The MDA amonut of the $L$. minor cultured in the Bulk $\mathrm{TiO}_{2}$ medium did not differ significantly compared to the control group. In another study, the toxic effect of Ag NPs were assessed by intracellular ROS production in L. gibba due to the induction of oxidative stress. When the plant was exposed to $10 \mathrm{mgL}^{-1} \mathrm{Ag}$ NPs, high fluorescence emission of the ROS sensor 
was observed when in proportion tothe control group. It is therefore noted that the formation of ROS is increased due to Ag NPs toxicity [27]. Again CuO NPs, CS-CuO NPs and copper sulphate have been reported to reduce in the $L$. gibba deceleration, inhibit photosynthetic activity, reduce esterase activity and induce ROS formation [77].

Malondialdehyde (MDA) is the final product ensue from the peroxidation of cellular membranes [76,78]. The increase in $\mathrm{H}_{2} \mathrm{O}_{2}$ concentration in cells under stress conditions is considered to be a general reaction to the stress. Researchers have noted that $\mathrm{H}_{2} \mathrm{O}_{2}$ induces plant defense induced defense systems, low amounts of MDA and high $\mathrm{H}_{2} \mathrm{O}_{2}$ in tolerant species [79,80]. Similar results were found in our study as in other studies. Our study, in the correlation analysis performed, the only, in the all groups of nano $\mathrm{B}$ was found to be negatively correlated between MDA and $\mathrm{H}_{2} \mathrm{O}_{2}$ and positive correlation between MDA and CAT at $100 \mathrm{mgL}^{-1}$ of micro B. Normally it is expected that the MDA and $\mathrm{H}_{2} \mathrm{O}_{2}$ levels expected to show a positive correlation, but the likely reason for this is that the cell has other toxicities other than free radicals. Because of $L$. minor shows toxicity to $100 \mathrm{mgL}^{-1}$ of micro $\mathrm{B}$, increased $\mathrm{H}_{2} \mathrm{O}_{2}$ caused the increase of CAT and MDA, which is an indicator of cell membrane damage. There are several possible reasons why no correlation results will occur in other doses of micro $B$. This may be due to the lack of toxic effects or blocking synthesis over the dosage required for the protein synthesis mechanism due to its extreme toxicity. This has been shown in previous studies, and in soybeans, in the case of B excess, the amount of total protein decreased in the B treated groups compared to the control group [81]. Similar findings have been found in the literature regarding the content of $B$ and plant protein [82]. It has been noted that in the B excess of Indian peas (Cajaunus cajan) it reduces protein content by destroying some proteins. This suggests that boron plays a role in nitrogen metabolism. In another study, the activity of nitrate reductase was reduced in B deficiency or excess, and it has been noted that the conversion of nitrate $\left(\mathrm{NO}_{3}^{-}\right)$to nitrogen dioxide $\left(\mathrm{NO}_{2}\right)$ and its binding to organic compounds via ammonium $\left(\mathrm{NH}_{4}^{+}\right)$is reduced.

\section{Conclusions}

Although L. minor can take up micro B particles more than the nano $B$, under experimental conditions, some nano $B$ treated groups have more MDA and $\mathrm{H}_{2} \mathrm{O}_{2}$ levels (e.g., $200 \mathrm{mgL}^{-1}$ ). That is, although micro $B$ are more abundant in the plant, nano $B$ is more likely to induced oxidative stress. In addition, significantly stimulated oxidative stress indicates that exposure to high doses of $B$ may create a risk of toxicity for nano and micro $B$ particles. As a result of our findings, further efforts should be made to assess the risk of nanotechnology applications so that the adverse ecophysiological effects of the aquatic ecosystem and the organism's nanoparticle exposure can be reduced and controlled. Furthermore, more careful conservation of nanotechnology wastes should be made and more sensitive to release surrounding environment.

\section{Acknowledgment}

This research article was supported by the Ordu University Scientific Research Projects (BAP) with code AR-1671.

\section{References}

[1] Elimelech, M., Gregory, J., \& Jia, X. (2013). Particle deposition and aggregation: measurement, modelling and simulation. Butterworth-Heinemann.

[2] Scientific Committee on Emerging and Newly Identified Health Risks. (2005). Opinion on the appropriateness of existing methodologies to assess the potential risks associated with engineered and adventitious products of nanotechnologies (SCENIHR/002/05). European Commission.

[3] Lead, J. R., \& Wilkinson, K. J. (2006). Aquatic colloids and nanoparticles: current knowledge and future trends. Environmental Chemistry, 3(3), 159-171.

[4] Dağlığlu, Y., \& Yılmaz Öztürk, B. (2018). Effect of concentration and exposure time of $\mathrm{ZnO}-\mathrm{TiO} 2$ nanocomposite on photosynthetic pigment contents, ROS production ability, and bioaccumulation of freshwater algae (Desmodesmus multivariabilis). Caryologia, 71(1), 13-23.

[5] Pan, B., \& Xing, B. (2010). Manufactured nanoparticles and their sorption of organic chemicals. Advances in Agronomy, 108, 137-181.

[6] Rico, C. M., Majumdar, S., Duarte-Gardea, M., Peralta-Videa, J. R., \& Gardea-Torresdey, J. L. (2011). Interaction of nanoparticles with edible plants and their possible implications in the food chain. Journal of Agricultural and Food Chemistry, 59(8), 3485-3498.

[7] Monica, R. C., \& Cremonini, R. (2009). Nanoparticles and higher plants. Caryologia, 62(2), 161-165.

[8] Yilmaz Öztürk, B., Dağlıŏlu, Y., Aşikkutlu, B., \& Akköz, C. (2018). Changes in pigment content of green algae (Desmodesmus sp. and Chodatodesmus mucranulatus) exposed to alumina oxide (AI2O3) nanoparticles. Biological Diversity and Conservation, 11(3), 64-70.

[9] Dağlıoğlu, Y. (2018). A comparison of the acute toxicity and bioaccumulation of boron particles (nano and micro) in chodatodesmus mucronulatus. Journal of Boron, 3(3), 157-165

[10] Fleischer, A., O'Neill, M. A., \& Ehwald, R. (1999). The pore size of non-graminaceous plant cell walls is rapidly decreased by borate ester cross-linking of the pectic polysaccharide rhamnogalacturonan II. Plant Physiology, 121(3), 829-838.

[11] Navarro, E., Piccapietra, F., Wagner, B., Marconi, F., Kaegi, R., Odzak, N., Sigg L., \& Behra, R. (2008). Toxicity of silver nanoparticles to Chlamydomonas re- 
inhardtii. Environmental Science\&Technology, 42(23), 8959-8964.

[12] Navarro, E., Baun, A., Behra, R., Hartmann, N. B., Filser, J., Miao, A. J., Quigg P., \& Sigg, L. (2008). Environmental behavior and ecotoxicity of engineered nanoparticles to algae, plants, and fungi. Ecotoxicology, 17(5), 372-386.

[13] Moore, M. N. (2006). Do nanoparticles present ecotoxicological risks for the health of the aquatic environment?. Environment International, 32(8), 967-976.

[14] Nair, R., Varghese, S. H., Nair, B. G., Maekawa, T., Yoshida, Y., \& Kumar, D. S. (2010). Nanoparticulate material delivery to plants. Plant Science, 179(3), 154163.

[15] Poslu, K., \& Arslan, İ. H. (1995). Dünya bor mineralleri ve bileşikleri üretiminde Türkiye'nin yeri. Endüstriyel Hammaddeler Sempozyumu [Symposium of Industrial Raw Materials], Turkey, 33-34.

[16] Bekish, Y. N., Poznyak, S. K., Tsybulskaya, L. S., \& Gaevskaya, T. V. (2010). Electrodeposited Ni-B alloy coatings: structure, corrosion resistance and mechanical properties. Electrochimica Acta, 55(7), 2223-2231.

[17] Zhang, X. W., Zou, Y. J., Yan, H., Wang, B., Chen, G. H., \& Wong, S. P. (2000). Electrical properties and annealing effects on the stress of RF-sputtered c-BN films. Materials Letters, 45(2), 111-115.

[18] Dyar, J. J., \& Webb, K. L. (1961). A relationship between boron \& auxin in C14 translocation in bean plants. Plant Physiology, 36(5), 672.

[19] Mittler, R., Vanderauwera, S., Gollery, M., \& Van Breusegem, F. (2004). Reactive oxygen gene network of plants. Trends in Plant Science, 9(10), 490-498.

[20] Shen, M., Haggblom, C., Vogt, M., Hunter, T., \& Lu, K. P. (1997). Characterization and cell cycle regulation of the related human telomeric proteins Pin2 and TRF1 suggest a role in mitosis. Proceedings of the National Academy of Sciences, 94(25), 13618-13623.

[21] Lin, Y. M., Zou, X. H., Liu, J. B., Guo, Z. J., \& Lin, P. S. S., 2005: Nutrient, chlorophyll and caloric dynamics of Phyllostachys pubescens leaves in Yoncghun Country, Fujian. China. Journal of Bamboo and Rattan, 4, 369385.

[22] Filella, I., Amaro, T., Araus, J. L., \& Peñuelas, J. (1996). Relationship between photosynthetic radiation-use efficiency of barley canopies and the photochemical reflectance index (PRI). Physiologia Plantarum, 96(2), 211-216

[23] Ayeni, O. O., Ndakidemi, P. A., Snyman, R. G., \& Odendaal, J. P. (2012). Assessment of metal concentrations, chlorophyll content and photosynthesis in phragmites australis along the Lower Diep River, CapeTown, South Africa. Energy and Environment Research, 2(1), 128-139.

[24] Kumar, P., Kumar, D., Sikka, P., \& Singh, P. (2015). Sericin supplementation improves semen freezability of buffalo bulls by minimizing oxidative stress during cryopreservation. Animal Reproduction Science, 152,
26-31.

[25] Vallyathan, V., \& Shi, X. (1997). The role of oxygen free radicals in occupational and environmental lung diseases. Environmental Health Perspectives, 105(suppl 1), 165-177.

[26] Manke, A., Wang, L., \& Rojanasakul, Y. (2013). Mechanisms of nanoparticle-induced oxidative stress and toxicity. BioMed Research International, 2013, 942916.

[27] Oukarroum, A., Barhoumi, L., Pirastru, L., \& Dewez, D. (2013). Silver nanoparticle toxicity effect on growth and cellular viability of the aquatic plant Lemna gibba. Environmental Toxicology and Chemistry, 32(4), 902907.

[28] Khataee, A., Bozorg, S., Khorram, S., Fathinia, M., Hanifehpour, Y., \& Joo, S. W. (2013). Conversion of natural clinoptilolite microparticles to nanorods by glow discharge plasma: a novel Fe-impregnated nanocatalyst for the heterogeneous Fenton process. Industrial\&Engineering Chemistry Research, 52(51), 18225-18233.

[29] Gill, S. S., \& Tuteja, N. (2010). Reactive oxygen species and antioxidant machinery in abiotic stress tolerance in crop plants. Plant Physiology and Biochemistry, 48(12), 909-930.

[30] Knaapen, A. M., Borm, P. J., Albrecht, C., \& Schins, R. P. (2004). Inhaled particles and lung cancer. Part A: Mechanisms. International Journal of Cancer, 109(6), 799-809.

[31] Risom, L., Møller, P., \& Loft, S. (2005). Oxidative stress-induced DNA damage by particulate air pollution. Mutation Research/Fundamental and Molecular Mechanisms of Mutagenesis, 592(1-2), 119-137.

[32] Oberdörster, G., Oberdörster, E., Oberdörster, J. (2005). Nanotoxicolgy, an emerging discipline evolving from studies of ultrafine particles. Health Perspective, 113(7), 823-839, 2005.

[33] Dewez, D., Dautremepuits, C., Jeandet, P., Vernet, G., \& Popovic, R. (2003). Effects of methanol on photosynthetic processes and growth of Lemna gibba. Photochemistry and Photobiology, 78(4), 420-424.

[34] Dağlıoğlu, Y., \& Öztürk, B. Y. (2019). A novel intracellular synthesis of silver nanoparticles using Desmodesmus sp.(Scenedesmaceae): different methods of pigment change. Rendiconti Lincei. Scienze Fisiche e Naturali, 30(3), 611-621.

[35] Dağlığlu, Y., \& Yılmaz Öztürk, B. (2016). The assessment of biological accumulation on exposure in boron particles of Desmodesmus multivariabilis. Biological Diversity and Conservation, 9(3), 204-209.

[36] Dağlıoğlu, Y., \& Yılmaz Öztürk, B. (2018). Effect of concentration and exposure time of $\mathrm{ZnO}-\mathrm{TiO} 2$ nanocomposite on photosynthetic pigment contents, ROS production ability, and bioaccumulation of freshwater algae (Desmodesmus multivariabilis). Caryologia, 71(1), 13-23.

[37] Beauchamp, C., \& Fridovich, I. (1971). Superoxide dismutase: improved assays and an assay applicable to 
acrylamide gels. Analytical Biochemistry, 44(1), 276287.

[38] Jebara, S., Jebara, M., Limam, F., \& Aouani, M. E. (2005). Changes in ascorbate peroxidase, catalase, guaiacol peroxidase and superoxide dismutase activities in common bean (Phaseolus vulgaris) nodules under salt stress. Journal of Plant Physiology, 162(8), 929-936.

[39] Mukherjee, S. P., \& Choudhuri, M. A. (1983). Implications of water stress-induced changes in the levels of endogenous ascorbic acid and hydrogen peroxide in Vigna seedlings. Physiologia Plantarum, 58(2), 166170.

[40] Sairam, R. K., \& Saxena, D. C. (2000). Oxidative stress and antioxidants in wheat genotypes: possible mechanism of water stress tolerance. Journal of Agronomy and Crop Science, 184(1), 55-61.

[41] Heath, R. L., \& Packer, L. (1968). Photoperoxidation in isolated chloroplasts: I. Kinetics and stoichiometry of fatty acid peroxidation. Archives of Biochemistry and Biophysics, 125(1), 189-198.

[42] Lewis, M. A. (1995). Use of freshwater plants for phytotoxicity testing: a review. Environmental Pollution, 87(3), 319-336.

[43] Geoffroy, L., Frankart, C., \& Eullaffroy, P. (2004). Comparison of different physiological parameter responses in Lemna minor and Scenedesmus obliquus exposed to herbicide flumioxazin. Environmental Pollution, 131(2), 233-241.

[44] Govorov, A. O., \& Carmeli, I. (2007). Hybrid structures composed of photosynthetic system and metal nanoparticles: plasmon enhancement effect. Nano Letters, 7(3), 620-625.

[45] Nadtochenko, V. A., Nikandrov, V. V., Gorenberg, A. A., Karlova, M. G., Lukashev, E. P., Semenov, A. Y., Bukharina N. S., Kostrov A. N., Permenova E. P., \& Sarkisov, O. M. (2008). Nanophotobiocatalysts based on mesoporous titanium dioxide films conjugated with enzymes and photosynthetic reaction centers of bacteria. High Energy Chemistry, 42(7), 591-593.

[46] Juhel, G., Batisse, E., Hugues, Q., Daly, D., van Pelt, F. N., O'Halloran, J., \& Jansen, M. A. (2011). Alumina nanoparticles enhance growth of Lemna minor. Aquatic Toxicology, 105(3-4), 328-336.

[47] Donaldson, K., \& Tran, C. L. (2002). Inflammation caused by particles and fibers. Inhalation Toxicology, 14(1), 5-27.

[48] Bouwmeester, H., Poortman, J., Peters, R. J., Wijma, E., Kramer, E., Makama, S., ... \& Hendriksen, P. J. (2011). Characterization of translocation of silver nanoparticles and effects on whole-genome gene expression using an in vitro intestinal epithelium coculture model. ACS Nano, 5(5), 4091-4103.

[49] Von Moos, N., \& Slaveykova, V. I. (2014). Oxidative stress induced by inorganic nanoparticles in bacteria and aquatic microalgae-state of the art and knowledge gaps. Nanotoxicology, 8(6), 605-630.
[50] Brunner, T. J., Wick, P., Manser, P., Spohn, P., Grass, R. N., Limbach, L. K., ... \& Stark, W. J. (2006). In vitro cytotoxicity of oxide nanoparticles: comparison to asbestos, silica, and the effect of particle solubility. Environmental Science\&Technology, 40(14), 4374-4381.

[51] Kaçar, B. (1977). Bitki besleme [Plant nourishment]. Ankara University Faculty of Agriculture Publishing.

[52] Davis, S. M., Drake, K. D., \& Maier, K. J. (2002). Toxicity of boron to the duckweed, Spirodella polyrrhiza. Chemosphere, 48(6), 615-620.

[53] Scheumann, V., Schoch, S., \& Rüdiger, W. (1999). Chlorophyll b reduction during senescence of barley seedlings. Planta, 209(3), 364-370.

[54] Turkis, S., \& Özbucak, T. B. (2010). Foliar resorption and chlorophyll content in leaves of Cistus creticus L.(Cistaceae) along an elevational gradient in Turkey. Acta Botanica Croatica, 69(2), 275-290.

[55] Odabaş, F. (1981). Bacchus çeşidinde (Vitis vinifera L.) yapraklarin klorofil miktari üzerine azot gübrelemesinin etkisi [Effect of nitrogen manuring on chlorophyll amount of leaves on Bacchus spp. (Vitis vinifera L.)]. Atatürk University Journal of Agricultural Faculty, 12(23), 39-50.

[56] Halliwell, B. (1994). Free radicals and antioxidants: a personal view. Nutrition Reviews, 52(8), 253-265.

[57] Murray, R. K., Granner, D. K., Mayes, P. A., \& Rodwell, V. W. (1996). Harper'ın Biyokimyası (N. Dikmen, T. Özgünen, Trans.), İstanbul: Barış Kitabevi. (Original work published in 1996).

[58] Commoner, B., Townsend, J., \& Pake, G. E. (1954). Free radicals in biological materials. Nature, 174(4432), 689-691.

[59] Harman, D. (1956). Aging: a theory based on free radical and radiation chemistry. Journal Gerontology, 11(3), 298-300.

[60] Paz-Elizur, T., Krupsky, M., Blumenstein, S., Elinger, D., Schechtman, E., \& Livneh, Z. (2003). DNA repair activity for oxidative damage and risk of lung cancer. Journal of the National Cancer Institute, 95(17), 13121319.

[61] Halliwell, B. (1994). Free radicals and antioxidants: a personal view. Nutrition reviews, 52(8), 253-265.

[62] Burke, J. J. (1995). Enzyme adaptation to temperature. In N. Smirnoff (Ed.), Environment and Plant Metabolism: Flexibility and Acclimation (pp. 63-78). BIOS Scientific Publishers.

[63] Halliwell, B., \& Gutteridge, J. M. (1990). Role of free radicals and catalytic metal ions in human disease: an overview. Methods in Enzymology, 186, 1-85.

[64] Caporaso, N. (2003). The Molecular Epidemiology of Oxidative Damage to DNA and Cancer. Journal of the National Cancer Institute, 95(17), 1263-1265.

[65] Ames, B. N. (1983). Dietary carcinogens and anticarcinogens: oxygen radicals and degenerative diseases. Science, 221(4617), 1256-1264. 
[66] Cross, C. E., Halliwell, B., Borish, E. T., Pryor, W. A., Ames, B. N., Saul, R. L., ... \& Harman, D. (1987). Oxygen radicals and human disease. Annals of Internal Medicine, 107(4), 526-545.

[67] Dumitrescu, C., Belgun, M., Olinescu, R., Lianu, L., \& Bartoc, C. (1993). Effect of vitamin C administration on the ratio between the pro-and antioxidative factors. Romanian Journal of Endocrinology, 31(1-2), 81-84.

[68] Smirnoff, N. (1995). Antioxidant systems and plant response to environment. In N. Smirnoff (Ed.), Environment and Plant Metabolism Flexibility and Acclimation (pp. 217-243). BIOS Scientific Publishers.

[69] Song, G., Hou, W., Gao, Y., Wang, Y., Lin, L., Zhang, Z., ... \& Wang, H. (2016). Effects of CuO nanoparticles on Lemna minor. Botanical Studies, 57(1), 1-8.

[70] Ames, B. N., Gold, L. S., \& Willett, W. C. (1995). The causes and prevention of cancer. Proceedings of the National Academy of Sciences, 92(12), 5258-5265.

[71] Guyton, K. Z., \& Kensler, T. W. (1993). Oxidative mechanisms in carcinogenesis. British Medical Bulletin, 49(3), 523-544.

[72] Taulavuori, E., Hellström, E. K., Taulavuori, K., \& Laine, K. (2001). Comparison of two methods used to analyse lipid peroxidation from Vaccinium myrtillus (L.) during snow removal, reacclimation and cold acclimation. Journal of Experimental Botany, 52(365), 2375-2380.

[73] Wang, H., Kou, X., Pei, Z., Xiao, J. Q., Shan, X., \& Xing, B. (2011). Physiological effects of magnetite (Fe3O4) nanoparticles on perennial ryegrass (Lolium perenne L.) and pumpkin (Cucurbita mixta) plants. Nanotoxicology, 5(1), 30-42.

[74] Dimkpa, C. O., McLean, J. E., Latta, D. E., Manangón, E., Britt, D. W., Johnson, W. P., ... \& Anderson, A. J. (2012). CuO and $\mathrm{ZnO}$ nanoparticles: phytotoxicity, metal speciation, and induction of oxidative stress in sand-grown wheat. Journal of Nanoparticle Research, 14(9), 1-15

[75] Zhou, D. X., Liu, Y. F., Liu, X. B. (2009). Effects of waterlogging stress on physiological and biochemical index in Alternant phiiloxeroides Hubei, Agricultural Sciences, 48(3), 585-587.

[76] Sharma, P., Jha, A. B., Dubey, R. S., \& Pessarakli, M. (2012). Reactive oxygen species, oxidative damage, and antioxidative defense mechanism in plants under stressful conditions. Journal of Botany, 2012, 217037.

[77] Perreault, F., Popovic, R., \& Dewez, D. (2014). Different toxicity mechanisms between bare and polymercoated copper oxide nanoparticles in Lemna gibba. Environmental Pollution, 185, 219-227.

[78] Cruz, F. J. R., Castro, G. L. S., Júnior, D. S., Festucci-Buselli, R. A., \& Pinheiro, H. A. (2013). Exogenous glycine betaine modulates ascorbate peroxidase and catalase activities and prevent lipid peroxidation in mild water-stressed Carapa guianensis plants. Photosynthetica, 51(1), 102-108.

[79] Burzyński, M., \& Kłobus, G. (2004). Changes of photosynthetic parameters in cucumber leaves under $\mathrm{Cu}$,
Cd, and Pb stress. Photosynthetica, 42(2), 505-510.

[80] Keyvan, S. (2010). The effects of drought stress on yield, relative water content, proline, soluble carbohydrates and chlorophyll of bread wheat cultivars. The Journal of Animal and Plant Sciences, 8(3), 10511060.

[81] Oluk, E. A., Latif, N. (2008). Soya fasulyesi (glycine max (I) merrill var. umut 2002) büyümesi ve gelişimi üzerine bor fazlaliğinin etkileri [Effects of excess boron on soybean (glycine max (I) merrill var. umut 2002)], Erzincan University Journal of Science and Technology, 1(1), 27-38.

[82] Bishnoi, S. K., Kumar, B., Rani, C., Datta, K. S., Kumari, P., Sheoran, I. S., \& Angrish, R. (2006). Changes in protein profile of pigeonpea genotypes in response to $\mathrm{NaCl}$ and boron stress. Biologia Plantarum, 50(1), 135-137. 